\title{
1881 年の神田橋本町改良事業に関する研究
}

\author{
その 1 橋本町一圓買上の経過とその性格
}

\author{
正会員石田頼房水
}

目: 次 ${ }^{12}$

はしぬに

1. 神田橋本町の火災前の状況

2. 1881 年1月 26 日の大火

3. 橋本町買上げをめぐる東京十五区镱時会の論議

4. 橋本町一円買上の実態

5. 橋本町買上の性格

はじめに

森鴎外が 1889 年に書いた論文「市区改正ハ果シテ衛 生上ノ問題二非ザル力」² ${ }^{2}$ 中で，他の衛生家達が方区 改正について論ずることの少ないのを訝かったらえわ ずかに存在する市区改正についてふれた論文を批判した ことは，柴田德衛氏の著作 ${ }^{3)}$ にり広く知られるように なった。即ち森鴎外は, 松山棟庵(が要スル所八市区改 正ノ方便习借リ夫ノ裏店习鳥有二帰シテ公衆衛生ノ事業 ヨ完結シ所謂東京ノ本地ヨシテ無恙ナル楽土タラシメン トスルニ在リ」と論じた5)のを䩦しく批判し「若シ論者ノ

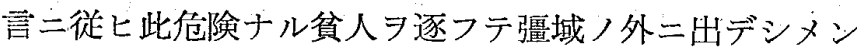
力是レ貧人卜俱二公衆ノ衛生 7 密外二抛ツ七ノナリ何卜 ナレバ㽬域内二留マリタル富人公篦ノ一小部分ナリ公 衆ニ非ザルナリ既二公衆ナシ豈又夕公衆ノ衛生アランヤ」 とのべている。松山棟痷の論文がのった大日本私立衛生 会雑誌には，この他にも市区改正に関連した論文がのっ ているが6)，その論調は森鴎外が「衛生論ノ此う如キ鍼 路二向ヘルハ方今我邦一般ノ攀ナリ」と述べているよう に，都市に火災の危険と不衛生をもたらしているのは貧 人の居住地であるとし，これを「中央市区」（東京の中 心市街地）から追放排除すべきたとするものが少なくな い。例えば, 同会理事高木兼寬汇「京橋, 日本橋, 神田 等〉如キ重モナル市区」に市区を縮小し，そこにのみ限 定すれば「市街ヨ 清潔ニシ下水ヨ疎通スル等百般ノコ 卜」を経済的に容易に抽なえるとし，そのため「下等 貧民ノ市内ノ住居二蜆へサル」ように「逐ハスシテ自ラ 去ラシムルノ方法」例えば平家建の禁止，特別税の賦課 などを提案している7)。

鴎外に批判された，このような貧民階層に刘する見方 と市区改正論俚，ただ単にこれ等の衛生大家だけのむの

* 東京都立大学 助教授・工博

(昭和 54 年 5 月 10 日本稿受理 - 討諭期限昭和 55 年 5 月末日)
ではなく，むしろ当時の当局者に一般的な思想であり， 新聞などにも同様な論調がみられた ${ }^{8)}$ 。更に実際の事業 として「市区改正ノ方便习借リ夫ノ裏店习烏有二帰シ」 「貧人卜俱二公衆ノ衛生与空外二拗ツ」よらなことも拉 こなわれていた。本研究でとりあげる 1881 年の神田橋 本町改良事業は，同町が従来から貧笨民の居住地であ り，公衆衛生上・防災上の問題が大きい地区とされ，か つ日本橋に隣接して「中央市区」の一画をしめていると いら点でも，又実際に多くの貧笨民が逐い払われたとい う点でも，この種の事業の典型ともいうべきものであ 当。

神田橋本町の改良事業については，従来注千代田区史 中巻9" 扝よび都史紀要 7 「七分積金」 ${ }^{10)}$ に非常に簡単に 紹介されているだけである。本研究は 1881 年の神田橋 本町改良事業の実態在詳細に明らかにすることによっ て，明治前期の日本の都市政策・都市阡画の一端を明ら かにすることを目的としている。

\section{1. 神田橋本町の火炎前の状況}

神田橋本町は江戸時代からつつくスラムで，特に「願 人坊主」の長屋の所在地として知られた所である ${ }^{11) 。 ~}$ 大火後, 神田区長の罹災者状況報告 ${ }^{12)}$ と橋本町一, 二丁目八従来遊惰甘貧ノ慣習ヨリ成立セシ一種異様ノ笨 民二シテ普通一般ノ貧困者ト大二情態ヨ別ニシ」とのべ ており，千代田区史によれば養肓院設立当時にも大改造 の計画があったといわれる ${ }^{13)}$ 。

表-1 注橋本町の 1872 年および 1881 年の户数・人 日・人口密度を示したものであるが，焼失当時で橋本町 1 丁目の 1611.4 人/ha を最高に各丁目と\& 1000 人/ha をこえる超過密状況であった。1筆の宅地における裏長

表一1 神田区橋本町开数人口及人口密度

\begin{tabular}{|c|c|c|c|c|c|}
\hline & 面 $\left(\right.$ 坪) ${ }^{\text {皘 }}$ & 年 次 & 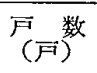 & 人 (人) & $\begin{array}{l}\text { 人口密度 } \\
\text { (人/ha) }\end{array}$ \\
\hline \multirow{2}{*}{1 丁目 } & \multirow{2}{*}{3011.15} & 1872 & 232 & 1509 & 1515.9 \\
\hline & & 1881 & 445. & 1604 & 1611.4 \\
\hline \multirow{2}{*}{2 丁目 } & \multirow{2}{*}{1947.25} & 1872 & 148 & 529 & 821.8 \\
\hline & & 1881 & 221 & 797 & 1238.1 \\
\hline \multirow{2}{*}{3 丁目 } & \multirow{2}{*}{1971.92} & 1872 & 177 & 665 & 1122.6 \\
\hline & & 1881 & 168 & 612 & 1033.1 \\
\hline
\end{tabular}

(注) 1872 年は「東京府志料」 1874 .

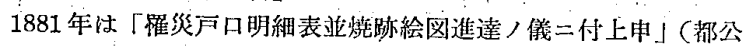
文書館) 
屋の例としては新銀町 23 番地（1 人平均地坪 1.05 坪）, 猿楽町 2 丁目 4 番地（同 1.17 坪）などの例が二代田区史 に紹介されているが14)，橋本町 1 丁目は居付地主 5 軒な どの 表店を含む 1 町丁目の平均值で 1 人当り地坪 1.88 坪となり，相当な逗密状況といえよう。

\section{1881 年 1 月 26 日の大火}

1880 81 年冬は東京の火桨史上最悪ともいえる冬で, 1880 年 12 月 30 日の神田鍛治町大火(2 188 户), 81 年 1 月 26 日の神田松枝町大火 (10637 戸), 2 月 11 日の神田 柳町大火 (7751 戸)，2月 21 日の四谷箪筍町大火 (1 499 戸）と 4 度にわたって大火があった他，頻々と火災が発 生し，放火に関する様々な風説がとんだ15! といわれる。

特に 1 月 26 日の大火は 明治時代最大級の市街地火災 といわれる。この火炎は ${ }^{16)} 1$ 月 26 日午前 1 時 30 分頃, 神田松枝町 22 番地より出火し, 同日午後 6 時 10 分まで 15 時間余にわたって然え続けた。焼失区域は神王・日 本橋・本所・深川の四区にわたり，10637巨を燒失，焼 失面積にして 127697 坪と記録されている。橋本町 1 ・ $2 \cdot 3$ 丁目では全焼戸数 831 . 戸，半焼戸数 3 戸と記録さ

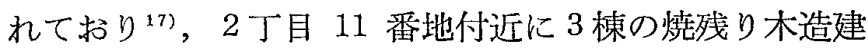
物があった他，20 棟以上の土蔵が残っただけであった。

\section{3. 橋本町買上げをめぐる東京十五区臨時会の論議}

東京府は大火後直ちに避難所の設置，炊出しなどの救 済措置をとるとともに，応急の家屋制限と恒久的な防火 対策をとった。応急策は, 1 月 29 日付で日本橋区役所と 神田区役所に対して出された「其区内去月三十日并本月 廿六日焼失ノ場所追テ何分之義相達候迄本家作取設之義 見合候様告示スヘシ此旨相達候事」といら府達である。 ひきつつき恒久的な都市防火対策として，以わゆる「防 火路線并二屋上制限規則」(東京府布達甲第二十七号 ${ }^{18}$ ) が2月 25 日に制定された。これは神田・京橋：日本橋・ 敖町の四区については，全ての建物の屋根を不燃材で莫 くことと，指定された防火路線ぞいでは，棟瓦石造・土 蔵造・石造のいわゆる三構造をもって建築することを定 めたものである。この恒久策の制定で本家作制限安撤廃 する 「其区内焼失跡地本家作取設方可見合旨兼テ相達置 候処今般甲第二十七号布達候二付テハ自今本家作取設， 儀不苦候 条右布達二照準可致旨告示 スベシ 此旨相達候 事」といら東京府達が同じく2 月25日に出された。

一方，東京府は橋本町 $1 \cdot 2 \cdot 3$ 丁目孛防災上・衛生上

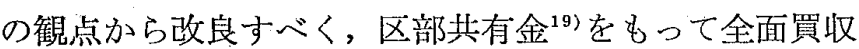
しよ5と計画し，これを議するため 1 月 29 日東京十五 区共有財産処分会 ${ }^{203}$ を招集した。

東京府知事松田道之は議案の提案に先だっておこなっ た演述の中で ${ }^{21)}, 1879$ 年の䇴屋町大火後に火防路線・ 屋上制限の制度をつくり，防火井を設け，河川を開削し ようと府債 75 万円の募集の議案を提出した時に府会が これを否決した事を想起させ，火災予防の急務であるこ
とと橋本町買上げが深い関連があることを述べ, 衛生・ 火災予防・都你の体面の三点が「議題ノ因リテ関スル所 以」であると述べた。

提案された議題は次のようなものであった。

神田区橋本町八彷来細民輻䡍ノ地ニシテ其居住営業ノ者八 率ネ木銭安泊杯卜唱へ徆矮ノ家屋习設ケ僅少ノ宿泊料 躬民二翼与シ此二宿泊スル者八日々各所二乞五スルノ風習 ナシ無籍同様定業ナキ者ノ栄窟トナリ狭险ノ一家屋ニシテ夥 多ノ人員习雑居セシムルニヨリ其不潔不体裁ナル䒠二名状ス ヘカラス維新後今日二至ル迄其跡ヨ一掃スル能ハス故二前年 悪疫流行ノ際該地殊二甚シク殆ント救フ可ラサルノ惨毒习遈 クシ一般衛生上ノ妨害少ナカラス当時改良ノ方法ヨ案セシト 踓其機会 7 得ス然ルニ去ル二十六日大火災ノ節同町一圓焼失 二及ヒタル八改良／機至レリト謂フヘシ依テ此際該地ヨ買収 シ十五区共有地トナシ更二普通ノ営㩍ヨナス者へ貸与シ従来 ノ整習ヨ一洗セントス則于該地買入費用ノ概算等左ノ如シ

一. 橋本町壱丁目ヨリ三丁目マテ民有地六千六百五拾坪三合 此買上代金六萬七千五百三円但壱坪二付平均金拾円ノ見 積

右買入八代金八十五区共有金定期預ケ222／内ヨリ一時支出ス へキモノトス搷地所八十五区共有財産二編入シ其収益八每 年十五区共有金へ収入スヘシ但シ地所買上等ノ金額八目下急 遽調查セルニヨリ実施ニ至リ多少差違ヨ生スルハ止习得サル モノトス

一. 橋本町地所買入代金八前条／如ク一時共有金习以テ支弁 ノ方向ナラン歌又ハ十五区共有地タル神田柳町壱番地ヨリ四 番地マテラ此際売払右買上ノ代価二充テ猶不足ノ分八現金 以テ支弁ノ方可ナラン知本会ノ可否決スル所二ヨルヘシ

この議案に府当局の橋本町に対する見方, 買上に至る 経過などが良く出ており，1881 年以前にも橋本町改良 のくわだてがあったことも示されている。十五区共有財 産処分会の結論は, 議案の第一項, 橋本町一円買上げの 件は，種々の意見は出たものの 1 名の反対で可決となっ た。その資金として柳町共有地を売却するという議案第 二項は，その必要なしとして削除された

結論に至るまでの議論恃錯雑としているが，次の 5 点 に整理できる。

(1) 橋本町に従来居住していた笨民はどうなるである らか，どの様な好置をとるか。

(2) 地主が買上げを拒むようなことはないか，すべて の土地索強制的に買上げる必要があるか。

(3) 買上地（および焼失地一般）にお打る建築制限は どのような内容にするのが適切か。

(4) 買上げ洒格は妥当か。

(5) 買上げ後どの様な人に，どの柍な条件で貸付ける のか，借り手はあるだろうか。

これらは，いずれも神田橋本町改良事業を検討する上 で見落すことが出来ない重要な点であり，本研究が解明 しようとする問題点でもある。

まず十五区臨時会議事録によって，これらの点をめぐ る論議をあとうけてみよう。 
従来居住していたよらな貧穿民を橋本町汃ら一掃する こと自体についての異論は全く出なかった。唯一人橋本 町買上げに反対し廃案を主張した関博直も「果シテ目的 ヨ達シ得レバヨシトイヘドモ此所ヨ若シ払フトキハ他ニ 集リ又一聚落ヨナスヘシ」「他ニ一ノ橋本町 クニテ八何ノ益モナカルヘシ」という立場からの反対で あった。橋本町の貧窮民が他町に移り住む「其弊八如何シ テ防キ得认゙手ヤ」は，他の議員も含めて共通の問題意識 であった。これに対し提案の説明に当った府当局は「此 所二住ミ来リシモ/此後八何方へ行クヤト云フ八其辺ノ 所二心配ナキニアラスト雖モ他町ニモ貧民，住ム場所モ アリテ芝新網町ナトノ類アレトモ多分聚団セサレバ左程 ノ害モナシ故二散布シ宁住マシ云ル)目的ナリ（傍点引 用者)」と答えている。議員の多くは，もっと強引に，「此 貧民八此繁昌ノ地二止り居ルコトハナラ又様ニナスヘ シ」「此輩习散居セシムレバ禹 7 衣服ノ所々ニ分ツカ如 ク却テ蒠延モ計り難シ因テ此人種八朱引地外ナトへ送! 都下二置ヌ様ノ注意」をすべきだとさえ主張している。 この議論（これは本研究その 3 で見るように実際に行な はれたことでもあるが）、，鴎外に批判された衛生大家 達の主張と軌を一にしたものであった。これにくらべれ ば橋本町買上に反対したわけではないし，貧民のために 具体的刘策を要求したのでもなかったが，田口卯吉 ${ }^{24)}$ 「今橋本町二居ルモノ八他二移ルモ営業二差支八ナキ ヤ」と質問しているのは，唯一橋本町の貧民を考えた発 言でめった。乙かしここれに対して府側は「多ク八出商 人ニシテ其家二於テ商唄ヨセサルモノナレバ之レヨ他二 移スモ別二不便ハアルマシ」と簡単に片うけ, 田口卯吉 も深くは追求していない。

買上を拒むものに対しての措置は，この買上げが「御 用」ト称シ買上クル」に近い性格のものか「買上习願 フモノノミ買ヒ上ル」任意に近いものかによって異なっ て来る。「規則二背カヌ」「相応普通ノ建築ヨスルト云 フ」地主に関しては，その意にまかせたらどらかという のが議員達の主張であった。府側は始めは「一般公共ノ コトナレバ数人ノ内一人ノ不服ハー己ノ私論ナレバ言 状ノ立ツ筈ニテナカルヘシ」と強い姿勢を示し「必入買 ヒ上テ別ニ之レヨ貸渡ス見込ナリ」としていたが,後には 「若シ本人希望等アルトキハ臨時ノ所分モアルヘシ文年 来居住営業シ居ル類モアランガ左様ノ類八買上ノ上直チ 二其人二貸付スベシ」とのべ，「理事者ノ臨時ノ所分二 任セラレタシ」と，必ずしも全面買上でない場合も有り 得るといらニュアンスになった。これも後に述べるが買 上に反対する地主が出たし, 居付地主には切坪で買上除 外を認めることになったのである。

買上地に括ける建築制限に関して府側は「別二見込习 斯ク斯クト云ニアラサレトモ尋常一般ノ町並卜ナサンコ トヨ欲スル」として「徆矮ナル家屋」ではなく「非常ノ
家屋」であれば良いとして㧍り，橋本町買上が，火災防 止を標榜しながらも, 主として衛生上の問題から考えら れていたことがわかる。十五区会の議論では, 福地源一 郎 ${ }^{25)}$ なから, 焼跡からはじめて一般に建築構造制限法 を設けよとの意見が出て, 賛成も多かったが, この点は 防火路線や市区改正の全体的決定にゆだねようというこ とになった。前述のように，その後 2 月 25 日に「防火 路線并二屋上制限規則」がつくられ，燒失地はこれに従 らよう指示されることになった。

買上価格は，府側原案では「壱坪二付平均金拾円」之 なっており「其近傍ノ見合セテ比較シタル迄ノコト」で あるが「随分相応ノ価ノ積り」とのべている。又, 議員 も, 平均 72〜3 等 ${ }^{26)}$ ならば実に至当の見積りとしてい る。地主代表が多いとい阮れる議員の意見がこの様であ ったし，また，事実，相当有利でもあったので大した議 論にならなかった。なお，この日の十五区臨時会は傍聴 禁止になっていたが，その理由は「地主ノ之レヨ聞知ス ルモノ或八其価ヨニニスルノ恐レナシトスヘカラサルナ リ」と，地価騰貴，地価つりあげを恐れたものである。

買上後の土地に借り手がいるか, 誰に貸し与えるかに ついて，十五区会への原案には「普通ノ営業ヨナス者 へ貸与」するとし，同会議で出た質問に対しても「尋常 ノ家屋习建ツルモノ」としか答えておらず, 甚だ便利な 土地だから喜んで借手が集るだろらという楽観的見通し であった。其後の経過では，誰に貸すかが俄然大問題と なり，6月に再び府区部会（十五区会に相当）で論議さ れ，大火後 5 万月たってようやく貸付方針の確定をみて 7 月 14 日より「普通ノ営業ヨナス」「尋常〉家屋ヨ建ツ ルモノ」に貸与をはじめるが，必ずしも多くの借り手が 集る様な状況ではなかった。橋本町買上は, 貧民を追い 払い「散布シテ住マシムル」のが目的であったから，後 の経営のことは深く考えなかったというべきだろう。十 五区会の議論でも「此地所買上八差急カネバナラヌコト ナリ又共有金モ定期預ケニナシ置クョリ八利益アルモ知 ルベカラリレバ...」「金力地面ニ代ル迄ノコト不得已二 臨テ二割モ損スレハメ元ノ金トナルヘシ何モ多言二及バ ズ」といら論理で，ともかく買上を急いだのである。

\section{4. 橋本町一圓買上の実態}

橋本町 $1 \sim 3$ 丁目の 45 筆の地主は, 表一 2 に示したよ 万に33名である。 5ち橋本町居住地主は15 名, 不在地 主は18名である。不在地主の中には; 三井組の三井三 郎助 ${ }^{27)}$, 日本橋横山町の天野源七 ${ }^{28)}$, 浅草御蔵前片盯の 青地常太郎 299などのよらに各地に土地を所有する宅地地 主層もいた。地主の中で最も所有規模の大きいのは前記 天野源七の 2 筆 693.63 坪, 居付地主で注質耐替渡世:小 山伊兵衛 (妻志加名儀含む) の4筆 529.59 坪である。 最小は大工職木村茂との 1 筆 52.20 坪で, 平均 210,95 坪であった。 
表一2＼cjkstart橋本町買上㴍数・買上洒格および地主名

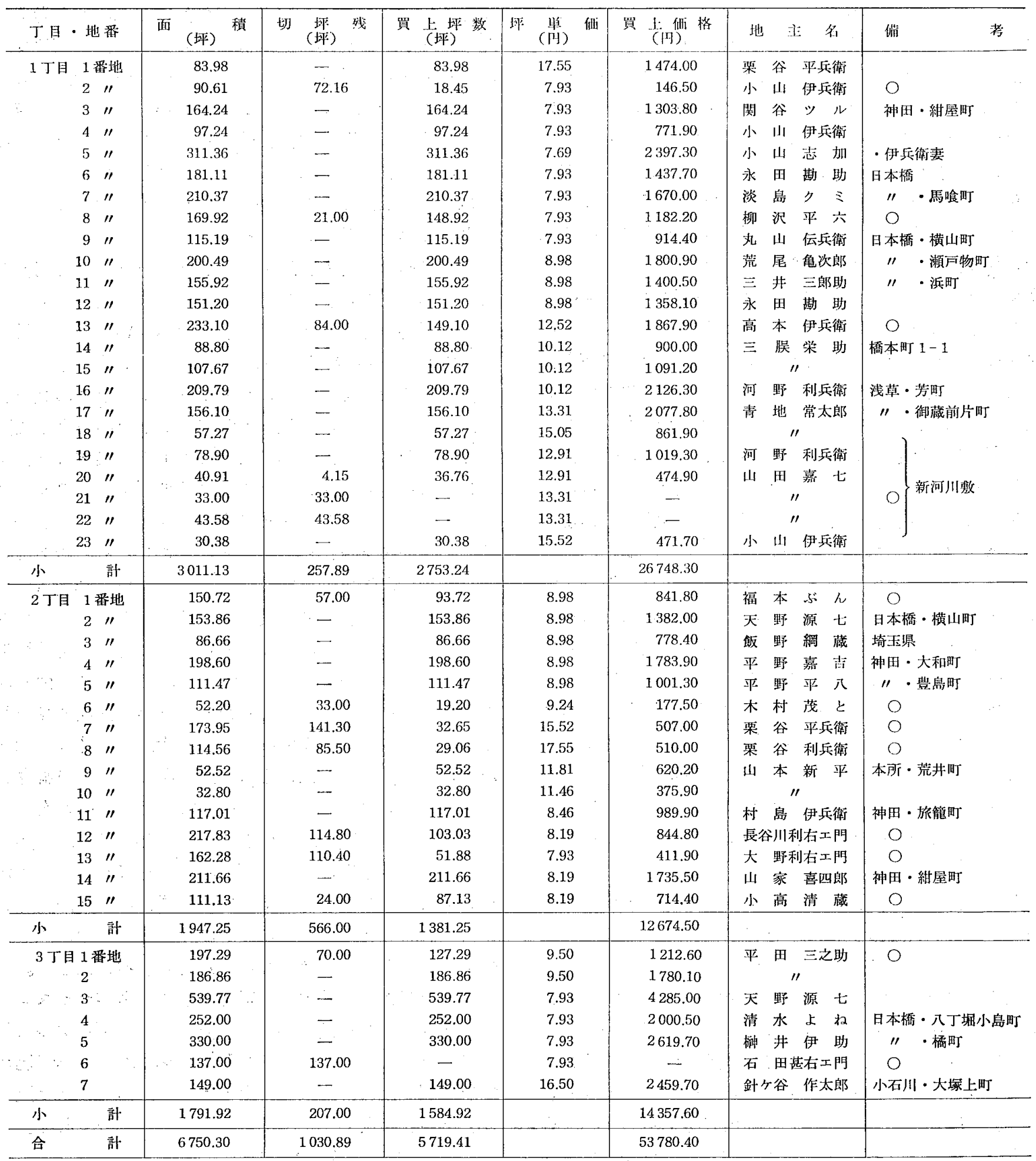

（注）・地所買上請書㧍よび買上代金渡押切仕訳書（都公文書館）による

買上の件に関して十五区臨時会の議決を得た 東京府 は; 翌 1 月 30 日に地主 32 名を神田区役所に呼び出し; 区長から府庁の旨意, 十五区臨時会決議を諭達し，地所 買上にかかった。

都公文書館蔵の『明治十四年区部共有地回議録』の緅 にある文書で見る限り，この経過は次の栐である。全地 主中，居付地主の旅人宿渡世石田甚右衛門括よび埼玉県 在住の不在地主飯野綱蔵を除く 31 名から 2 月 4 日付で 下記の様な「地所買上請書」が提出されている。な抢買
- ○印は居付地主

上請書に記載された買上坪数・代金は，次にのべる「切 坪残し」を含んだものであって, 実際の買上面積・価格 とは異なる。

\footnotetext{
橋本町壱丁目壱番地 一. 八拾三坪九合八勺 壱坪二付金拾七円五拾五銭 此合 千四百七拾四门 但端数切捨 右代価二テ御買上之旨承知仕候也
} 
明治十四年二月四日

東京府知事 松田道之殿

橋本町居住の地主のうち, 小山志加, 石田甚右衛門, 三脵栄助の 3 名を除く 12 名からは買上請書と前後して 「居付地主居住地切残願書」が図面つきで提出されてい る。その例をかかげれば次のよらなものである。

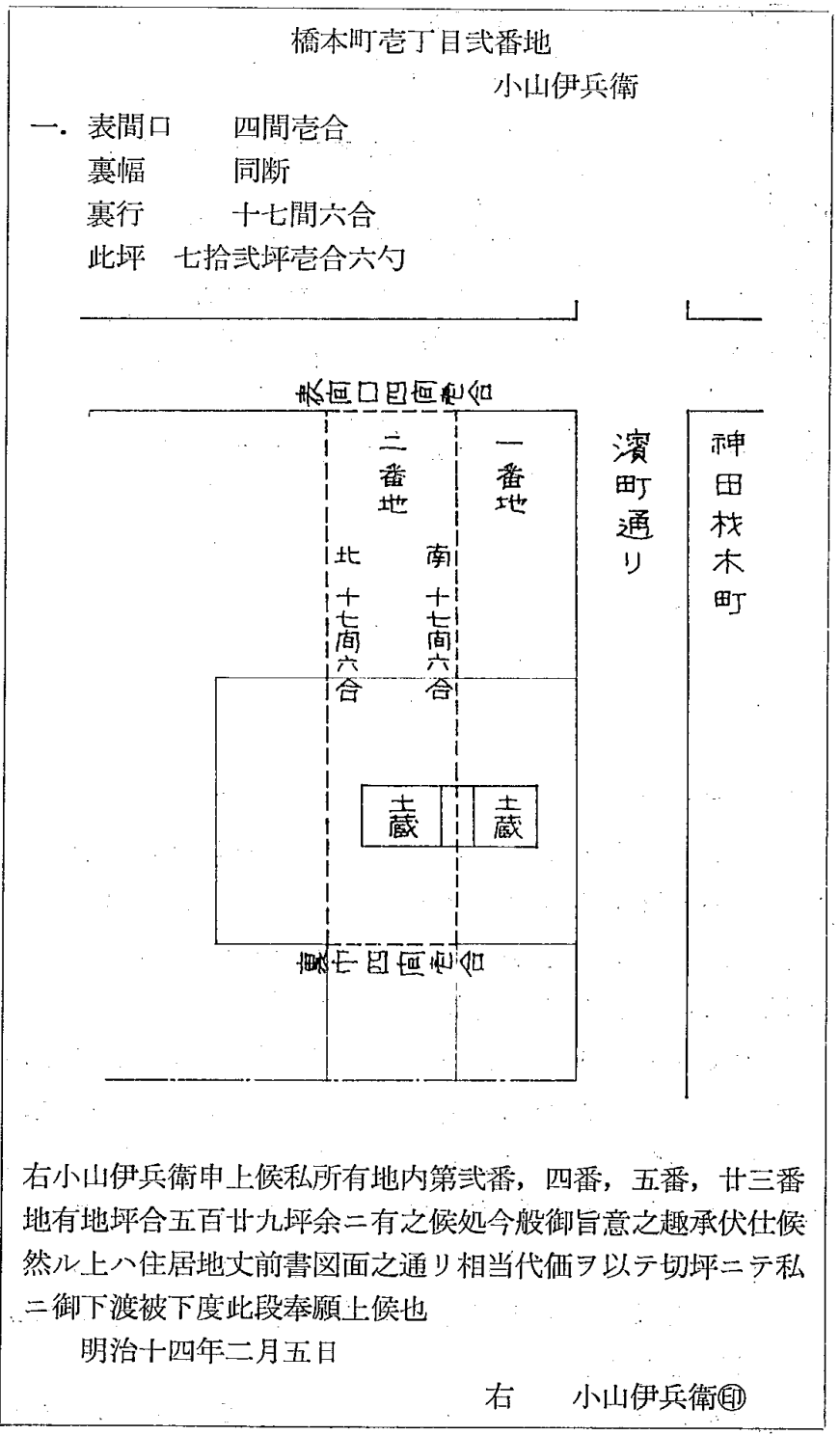

ひきつつき 2 月 8 日から 2 月 10 日にかけて買收代金 が神田区役所を通じて支払われ，地券が地主から上納 ${ }^{30)}$ されて買收が完了した。大火による焼失から半月，十五 区臨時会決議から 12 日間，一見きわめてスムーズにお こなわれて, 十五区臨時会で「若シ迷惑ノ地主申合セ之 レタ売ラスト拒マ八如何所分セラルルヤ」などと心配し て議論したことは全くの取越苦学であったかの様であ る。

しかし，この買収もとれ程順調ではなかったことが新 聞記事などかららかがわれる。1月 30 日に呼び出された 地主のらち，居付地主 11 名は「熟考す心゙き次第もあれ ば来る三日まで確答猶予の儀を出願」したと報じられて 㧈り ${ }^{31)}$ ，また同町一丁目十七番地十八番地の持主青地常 次郎は迷惑千万の儀などとて未だ請書を差出さず又三
丁目六番地の持主石田甚右衛門も右同様苦情を申しおれ ど此方は值段さへよければ手放す量茪ならんとの噂」な どの記事 ${ }^{32)}$ も見える。十五区臨時会で懸念された地主の 反対は現奏におこったのであるが,府当局は「一二人ノ不 服八一己ノ私論ナレバ言状ノ立ツ筈ニテナカルヘシ」と いら強い態度でのぞんだから「段々の説諭に服してお請 なせし」33)といら結果になった。しかし石田甚右衛門は 結局請書を提出せず, 全居付地主中ただ一人, 全地坪買 残しとなった。他の居付地主は, 前述のように一度全地 坪に対して「買上請書」を提出し，その上で「切坪ニテ 御下渡」を願い出る形式をとっているから，形の上では 石田甚右衛門は買収拒否になる。二丁目六番地の木村茂 とは, 所有土地 52.20 坪の内, 表地の 33 坪を「切坪残 し」とし裏宅地及路地 19.2 坪を売渡したが, その後裹 宅地を借り受け出願し許され，結局全体を利用している ことなどと対比しても，石田甚右衛門の場合は特例であ 万。

1 月 30 日に神田区役所に地主一同が呼び出された時, 三井組手代が「諭達を抨聴するや直に承諾の旨を発言せ し」といらことがあったといわれ，このことが他の地主 の不満をのべる機を失なわせたようで「四五名の地主は 烟に巻汃て私も異存なしと斿をせし者もありし由」 と新聞 ${ }^{34)}$ に報じられている。

各筆の 買収坪数 招よび買収価格は 2 月 10 日現在で みれば 表一2 に示したと拈りである。全体で買上面積 5719.41 坪, この価格 53780 円 40 銭で, 平均坪単価 9 円40銭であった。府が十五区臨時会で提案した予定単価 10 円よりはやや安めに買収出来たわけである。この内橋 本町 1 丁目18番地 23番地の 284.04 坪 (切坪残 し 80.73 坪，共有金買上 203.31 坪）は防火路線としての 新川開 鉒用地として官費買上となったし ${ }^{35)}$ ，また，2丁目 1 番 地福本ぶんは 5 月 7 日になって他へ地所を求めて移転す るという理由で切坪残し分の 57 坪を再度買上てほしい と願い出て, 坪単価 8 円 93 銭, 総額 511 円 86 銭で買上

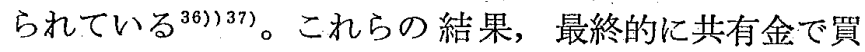
上られた土地は 5573.15 坪この洒格 51464 円 40 銭とな ったわけである ${ }^{38)}$

ここで買收単価について見ると, 最高は 1 丁目 1 番地 （浜町通り・橋本町通り角地）および 2 丁目 8 番地（人右 衛門町通り・橋本町通り角地) の 17 円 55 銭, 最低は 1 丁目 5 番地の 7 冈 69 銭である (図一 1 参照)。なお 1878 年 (明治 11 年) の土地評洒額 ${ }^{39}$ とを比較したのが 表一3 である。この 1878 年評価額による各丁目の上地価格は 1 丁目 10211 円 82 銭 7 厘, 2 丁目 6661 円 32 銭 3 厘, 3 丁目は 5555 円 99 銭 9 厘；合計 22389 円 14 銭 9 厘で あり, ‘平均坪単価 3 円 32 銭である。実際の買収価格は その約 2.9 倍にあたる。1881 年当時の実際の壳買価格 は平均 6 円 50 銭位といわ机ており ${ }^{409}$ ，これと比較して 


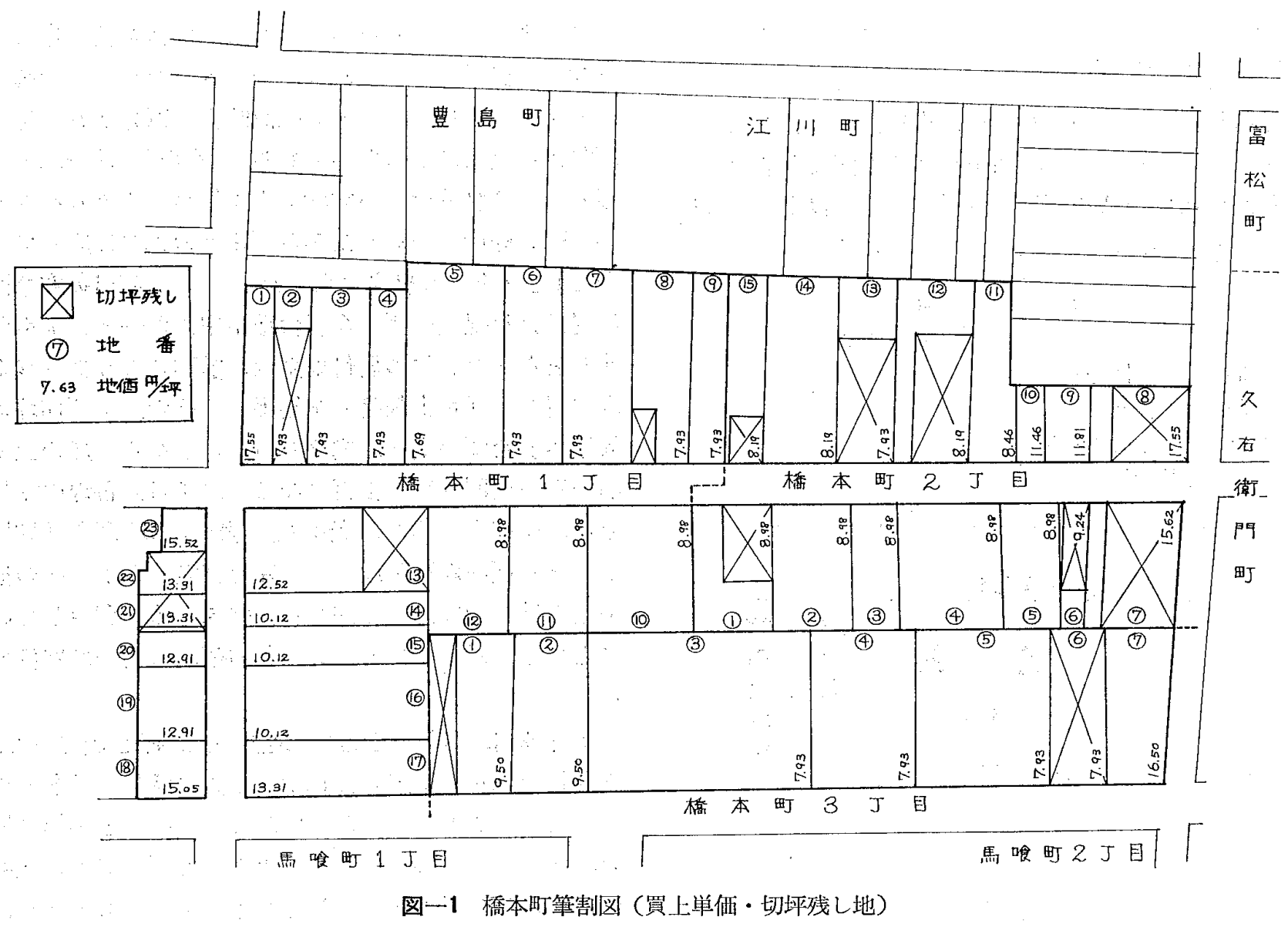

表一3 橋本町土地等級・評価額と買收価格

\begin{tabular}{|c|c|c|c|c|}
\hline \multicolumn{3}{|c|}{ 1878年 1 月議定 } & \multirow{2}{*}{ “当 地 䧽 } & \multirow{2}{*}{ 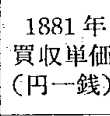 } \\
\hline $\begin{array}{l}\text { 土地等級 } \\
\text { (等) }\end{array}$ & $\begin{array}{l}\text { 貢 貸価 格 } \\
\end{array}$ & $\begin{array}{c}\text { 坪当価格 } \\
(\mathrm{I})\end{array}$ & & \\
\hline .53 & $4.09 \sim 3.89$ & 6.05 & $1-1,2-8$ & 17.55 \\
\hline 55 & $3.85 \sim 3.74$ & 5.69 & $3-7$ & 16.50 \\
\hline 57 & $3.62 \sim 3.52$ & 5.36 & $1-23,2-7$ & 15.52 \\
\hline 58 & $3.51 \sim 3.41$ & 5.19 & $1-18$ & 15.02 \\
\hline 62 & $3.10 \sim 3.02$ & 4.59 & $1-17 \cdot 21 \cdot 22$ & 13.31 \\
\hline 63 & $3.01 \sim 2.93$ & 4.46 & $1-19 \cdot 20$ & 12.91 \\
\hline 64 & $2.92 \sim 2 ; 84$ & $4: 32$. & $1-13$ & $12: 52$ \\
\hline 66 & $2.75 \sim 2.68$ & 4.07 & $2-9$ & 11.81 \\
\hline 67 & $2.67 \sim 2.60$ & 3.95 & $2-10$ & 11.46 \\
\hline 71 & $2.36 \sim 2.30$ & 3.50 & $1-14 \sim 16$ & 10.21 \\
\hline 73. & $2.22 \sim 2.16$ & 3.29 . & $3-1 \cdot 2$ & 9.50 \\
\hline 74 & $2.15 \sim 2.10$ & 3.19 & $2-6$ & 9.24 \\
\hline 75 & $2.09 \sim 2.04$ & 3.10 & $1-10 \sim 12,2,-1 \sim 5$ & 8.98 \\
\hline 77 & $1.97 \sim 1.92$ & 2.92 & $2-11$ & 8.46 \\
\hline 78 & $1.91 \sim 1.86$ & 2.83 & $2-12 \cdot 14 \cdot 15$ & 8.19 \\
\hline 79 & $1.85 \sim 1.80$ & 2.74 & $\begin{array}{l}1-2 \sim 4.6 \sim 9 \\
2-13,3-3 \sim 6\end{array}$ & .7 .93 \\
\hline 80 & $1.79 \sim 1.75$ & 2.66 & $1-5$ & 7.69 \\
\hline
\end{tabular}

(注) 1878 年土地等級等は「下古不枋東京地所明細」尚玄堂 1878 年. 1881 年買收価格は「地所買上請書」

毛買上価格法約 1.5 倍にあたる。1月 29 日の十五区臨時 会では「地券面卜云モ酷ナレバ地代金へノ式割三割等ノ 歩増アリタシ」と地主層の意見を代表した議論や，ある Wは地所等級が平均 $72 \sim 3$ 等ならば「一坪拾円八実二至 当ナ見積卜考へダリ」などの意見が出されたが，実態 としては地主にとって有利な価格ではなかったかと思わ

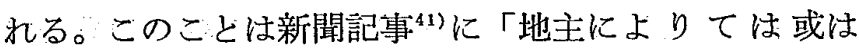
之を幸ひとなし平均一坪九円前後ならでは売り放つを拒
むものもあらん」あるいは「中には坪十五円に買上げて 黃ひたいと途方もない相場を申しおる者もある由」など と書かれていることからも察することが出来る。三井組 手代が淔に承諾したのも単に買上が「御用」に近い性格 のものであったといらだけではなく，買上価格が満定の 沙くものであったからでもあろう。な打 1 丁目 2 番地, 2丁目 13 番地のように裹地だけを買収された場合でむ 表地を含む価格で買収されているのは，貸付時には表地 （奥行 5 間まで）と裹地とで地代に差をつけていること

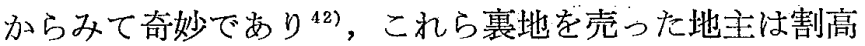
に売却出来たことになる。

切坪残し地は 図一 1 に示したように橋本町 $1 \sim 3$ 丁目 の各所にばらばらに存在している。各地主の所有地の中 から，どの様な理由で，いかなる部分を切坪しているか は必ずしも明らかではない。切坪残し地積でも 141.3 坪 から 21.0 坪まで, 切坪残し率でも $100 \%$ から $12.4 \%$ 东 で大きな幅がある。又，必ずしも自己居住又は営業用地 だけが切坪残しされているのではない。例えば，2丁目 7 番地栗谷平兵衛の切坪残し地と買上地にまたがって借 地人山添由太郎拉よび鈴木源助の焼残り土蔵があったこ とは雨名から出される拝借願からわかる。又，1丁目 1 〜 3 番地は土地の筆割は橋本町通りを間口として割られ ているが，利用上は浜町通りを間口として分割されてい た関係もあって，1丁目 2 番地小山伊兵衛の切坪残し地 には橋本町通りにそった部分に 1 丁目 1 番地にまたがっ て借地人三脵栄助の土蔵がたっていた（前揭小山伊兵衛 
切坪残し願書, および本研究その 3 所載の三脵栄助地所 扞借願の付図参照)。居付地主に対する切坪残しは, 形 式的にではあるが，一旦全面買上げて，願により下渡す方 法をとっていたから；所有と利用の喰い違いをなおすこ とも可能であったし, ”胒栄助のように 1 丁目 $14 \cdot 15$ 番 地を所有し， 1 丁目 1.2 番地の一部を借地して利用して いたものには替地として現在利用地を下渡すことも可能 であった。更に, 切坪残し地の介在が道路の新開等に支 障にならない様に配慮することも必要であった。しか し，この段階では，府当局にもそれだけの計画性はなか ったのである。

\section{5. 橋本町買上の性格}

橋本町買上の目的として, 衛生・火災予防・都府の体 面の三点があげられていたが，当時計画されつつあった 市区改正の一環といらことも全くなかったわけではな い。十五区臨時会の論議の中でも「勿論道路〉改正等迄 アリテ然ルヘシ」といら意見がのべられ，府側も「市区

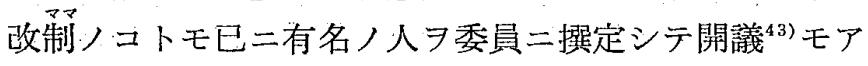
リシカ市区ノ改良八如何ナルヤ知ルベカラザレドモ」と しながらも「郡代ヤシキ44) モ大道习二条ヒラキ四方通行 ヨナサシメ之二橋本町习改正スレバ三角)地面二三条， 大道出来裡店ヨ変シテ表店トスルノ見込」であり,「又 橋本町八横町ナケレバ近傍二比シテ通路ヨモ開クヘキ見 込ナリ」と市区改正に関する方針を述べている。しかし， これに関する計画図らしきものは，後に述べる「遠藤万 兵衛計画図」しか残されて抢らず，実際に改良事業の中 で作り出される道路パターンはこれとも異なったもので ある。買上地の中から新道路敷として地券面上区分され たのは, 1 丁目 9 番地の 48 坪と 1 丁目 10 番地・ 3 丁目 3 番地にまたがる 107.4 坪の計 155.4 坪である。前者は 橋本町通りから豊島町へ抜ける二間道路, 後者は橋本町 通りから馬喰町 1.2 丁目方面へ抜ける三間道路 ${ }^{45)}$ として 考えられていた。それ以外の道路・通路は幅員の大小に かかわらず，地券面上は宅地であり，宅地内の大小路地 として作られることになる。郡代屋敷をつらぬく二本の 「大道」る確加に開かれることになるのだが，橋本町改 良と直接的には結びっかない。しっかりした改正計画の ないまま, 切坢残し, 焼残り土蔵の保存などが決ってい ったため, 事実上大規模な改正の余地はせばめられ「裡 店ヨ変シテ表店トスル」ような性格の事業になりにくく なったのである。

この様に神田橋本町改良事業は地所買上段階で, 貧民 を橋本町から逐い出し「散布シテ住マシムル」ことだけが 明らかになっていて, 買上後の市区改正や誰に土地を貸 付けてどのような建物を建てさせるのかなどの点を明ら かに出来ていなかった。森鴎外注前揭論文 ${ }^{46)}$ で過密な裹 店長屋をそのままにはして新けないといら事を述べ，ま た「欧米諸国二買上規則（「エキスプロプリヤチオンス，
レヒト」) ナルモノアアリテ狭险ニ過グルノ街路ト緻密二 過グルノ民居八之ヨ毁廃シ之ヨ蕩掃スルノ権习市庁二与 ヘタルラ知レリ」と欧米のスラムクリアランスの制度に ついてもふれているが，同時に「之户用主主主；其富

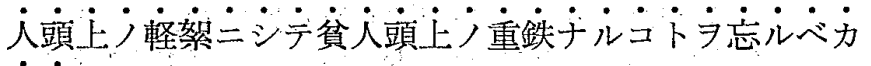
ラズ」とのベスラムクリアランスがもたらすものが階級 によって異なることも明確に述べている。まさに橋本町 買上は，三井組をはじめとする地主層にとっては軽絮で 西り(いやむしろ偾倖に近いかもしれない), 逐い出され る貧窮民にとっては重鉄以外の何ものでもなかった。鴎 外は更に，欧米諸国では買上規則を実行するのに限界と 約束があることを説明し，「余等八貧人二詨シテ「去レ ヨ」ト命ズルヨ好マズ若シ止ムヨ得ズシテ之ヨ命ズレバ 則于其応二何レノ処二向ッテ去ルベキカヨ預定セント 欲スルナリ」とのべ，貧人を外囲に移すことは適当では なく, 働き場所に近く安い住宅を与えるべきだと主張し ている。要するに逐はれる筫人に対し充分な対応策をお こなうことなく買上規則を発動するい゙きではないと論じ ているのである。十五区臨時会の議論の中で貧人の移住 先について主張した議員が一人だけ居たが，その説は 「此人種八朱引地外ナトへ送り都下二置邓様二注意アリ テ別二代地ヨ以テーツ，団聚所ヨ設ケタシ」といらもの であり，「何レノ処二向ッテ去ルベキカタ預定」すると いらより, まさに鴎外のいら「貧人卜俱二公羕/衛生 空外二拗ツ」意見の典型であった。

1) 本研究その 2 は副題「橋本町 お上び柳町の一括择借願に ついて」で, 内容日次は, はじめに, 1. 遠藤萬兵衛およ び岩崎弥太郎の拝借願，2. 東京府内部におりる共有地貸 付方針の論議, 3 , 遠藤萬兵衛の趣意書 および追願, 4 . 遠藤萬兵衛の橋本町改良計画，5. 残地恐皆貸付議案をめ ぐる府区部会の論議, 6 . 共有地貸付方針の決定, となっ ている。 又, その.3 は副題「普通営業人への貸付と貧笨 民のゆくえ」で，目次は，はじめに，1，橋本町貸付の実 態，2. 共有地貸付にあたっての選別，3. 共有地貸付に あたっての計画性；4，貧穹民のゆくえ，まとめ，である。

2）「東京医事雑誌」562 567 号 1889. に発表された。引用 法岩波書店「鴎外全集」. 28 巻 1968. pp. 129～144 に上 右。

3）柴田德衛「日本の都市閣題一初期の研究成果」《都市構 造と都市計画』東大出版会 1968. p. 207)。

4) 森鴎外は前揭諭文の中で批判の対象とした「㖨习市区改 正二容レタル医家， 引人」について「必ズシモ其名习拆 言スルタ要セズ」として明記していないが，松山棟庵と 長谷川泰である。松山棟庵は医家, 慈惠病院創立者。

5）松山棟庵「衛生上東京市区改正ノ必要习論ス」『大日本私 立衛生会雑誌』 29 号 1885. pp.: $22 \sim 30$.

6）鴎外は 前揭論文では「余ガ寡聞ヨ以テスレバ」医家二人 だけが市区改正を諭じているにすぎないとして，此の2 人を批判しているが松山棟庵，長谷川泰（「市区改正委員 諸君二望么」同誌 65 号，1888）の他にも市区改正にかか わる 10 数編が同誌にのっている。鴎外自身もこれらを読 んでおり, 在独時代に公表した Enthnographisch-hygienische Studie über Wohnhäuser in Japan (1888) の中 では他の諸論文，例えば高木兼寛の 2 論文 (次注参照) についても批判的に言及している。「市区改正八果シテ衛 生上ノ問題二非げルカ」では，なぜ高木論文（本文で紹 
介したように松山諭文と同様な趣旨である) を批判しな かったか汃からない。鴎外は前掲ドイツ語論文の自抄 (「日本家屋説自抄」) で滈本・松山の名前をあげている が批判的扱いでははない。

7）高木兼寛「裹家ノ建設八衛生上及経済上二害アリ」同誌 18 号 1884. pp. 15 19, 「東京衛生事務/执張八市区ノ 改正 $\exists$ 要ス」同誌 20 号 1885, pp. 4 9. 高木忙医学博士: 海軍軍医総監。

8）郵便報知新聞 3 月 5 日付社説「東京防火線路論」など。

9)『千代田区史中巻』1960. pp. 372 373。

10) 都史紀要 7 『七分積金』1960. pp. $237 \sim 239$.

11)：「願人坊主」は僧体の乞食で,天保改革当時,橋本町に 46 軒 の宿所があり你内 83 軒の過半数をしめていたといら（南 和男『江戸の社会構造』塙書房 1969. pp. 159 162).

12）神田区長「罹災者景沉之儀上申」明治 14 年 2 月 8 日（都 公文書館蔵『明治 14 年神田松枝町出火畫類』)

13）前揭，『千代田区史中巻』p. 372 .

14）「裹長屋人口地坪比例表」1884 年（同区史中巻 p. 375）

15） 2 月 15 日付郵便報知に「大風の日には市中へ火をつけ諸 方を焼払ふて 窮民の仕事ををぶやし......」などの札を何者 かが張り出して歩いているという記事がある。

16）火災の状況は『東京市史稿変㷋篇』 5 巻 p. 1090 の消防 本部门報告による。

17) 神田区長「罹災戸口明細科焼跡絵図進達 八儀二付上申」 （前揭『松枝町出火書類』）

18）明治 14 年警視庁東京府甲第 27 号。全文 9 条からなり， 第 1 条で 22 本の防火路線を指定し，第 2 条で防火路線に 括ける三棈造制限，第 4 条で 4 区屋上制限を定めている。

19）区部共有金は，江戸時代の町会所の「七分積金」に起源 を持つ会計で，1868 年 8 月東京府にひきつがれ，1870 年 1月まで積立がつづけられた。その後一時は営縊会議所・ 東京会議所などで管理運用されたが，1876 年より再び付 庁に移管され，土木事業・蒻民扶助事業などに運用され た。財座の内容は 金・銀・粐・地所 (1705 方所) - 建物 などであったが，地所に関しでは次第に処分され，1881 年当時は橋本町買上 との関係で 処分が論議される神田柳 町共有地（2663.83 坪）のみとなっていた。本来「七分 積金」は窮民救恤の目的であったが，その後身である区 部共有金が筧民逐出しの事業に使わ机るのは皮肉であ る（都史紀要 7、『分積金』1960,『東京都百年史』 1 巻 3 章 3 節,『東京都財政史』上巻. pp. 40〜。中巻 pp. 231～).

20）東京十五区会は，府会議員中十五区 選出者 55 名で構成 し，共有金に関する議決などを打こなっていた。1881 年 1月 29 日の十五区臨時会で㴘頭, 田口卯吉議員より十 五区会の法的根拠，共有金処分議決について 疑義が出さ れたが，結局多数決で共有財産処分は「十五区会二於テ 議スルモ更二差支へナシ」と決めた（『東京府会日誌，明 治 14 年』都公文書館蔵)。な押，この年 2 月 14 日の太政 大臣布告で「東京府京都府大阪符神奈川県区郡部会規則」 が定められ，これをうけて 5 月 26 日東京府甲 71 号布達 が出され，区部共有財産処分は以後区部会で論議された。

21）前揭『東京付会日誌』所収「東京十五区会臨時会議事録 第一号」による。以下同日の䧧事は全てこれによる。

22）当時，共有金定期預方は拾四万円あったといら。

23）柳町共有地は，この決定にもかかわらず 1881 年中に売却 されたとされている（都史紀要 $7 『$ 七分積金』(p. 230).

24）田口卯吉は経済学者・法学博士。「東京経済雑誌」社長 ·

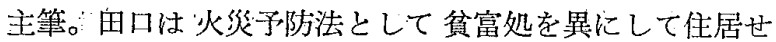

しむる方法に反対であるとの論文を書いている(「火災予 防論」東京経済雑誌 $54 \cdot 55 \cdot 56$ 号, 1881)。

25）福地源一郎は日袁社社長，東京日从新聞を主宰する。

26）穓貸伍格の評価等級。1878 年の資料によれば，73 等は 1 坪当り価格に換算して 3 円 29 銭程である。

27）三井組の橋本町に扮ける土地所有については, 玉井哲雄 「町屋敷内部の構造と町人地の変質 — 江戸町人地の研究 (4)」建築学会論文報告集 255 号 pp. 117 123，に江戸期 の状沉の資料がある。

28）天野源七の土地所有については，小林重敬「東京におけ る都市地所有と都市形成」日本都市計画学会学術講演諭 文集 6 号, 1971. pp. 15 20.

29）青地一族は 1912 年時点で 13875 坪余の 宅地を所有して いる。買上時に常太郎代理人となった幾次郎は府会議員。

30）地券上納に関して三井組から 2 月 8 日付で 2 月 15 日迄の 「地券上納猶予願」が提出されている。地券書かえは実際 は10月になってからおこなわれている。

31）郵便報知新聞 2 月 1 日付。

32) 同 2 月 3 日付。

33) 同 2 月 9 日付。

34) . 同 2 月 1 日付。

35）新川開鋚は 3 月 7 日に 拊区部会で区第五号議案として提 案された「濱町川堀留メヨリ東龍閑町习経テ神田川二通 スルノ新川」であり，この議案説明の中で「川敷民有地 官費買上ノ事ヨ政府二申請シ其允許习得タリ」とある。 したがって 1 丁目 20〜22で切坪残しとなった飴卸売渡世 山田嘉七は結局全地坪買上となり，後に 1 丁目 14 潘地の 土地扯偕を願出ている。

36）福本ぶんの返上した土地は，5月14 日付で福本利兵衛(ぶ んの買上請書に連署している)名で挷借願出て，7月 14 日 付貸付されているが，11月 2 日移転を理由に 返地してい る。移耺完了屯で従来の仮家作敷地として排借したもの であろら。

37）同様の再買上願は，1丁目8 番地の柳沃平六から 10 月 10 日付で出されているが，この件は不許可になっている。

38）『千代田区史』（中巻 p. 373）の共有金支出額はこれとほ ぼ一致しているが買上面積は 6650.3 坪としている。こ の面積任招々らく十五区会提案の議案記載の 全民有地面 積の数字が根拠と思われるが,これは議案の䛊記で実際の 民有地面積は 6750.3 坪。このうち買上面積は 5573.15 坪が正しい。

39）この怦価額は 1878 年 9 月刊『千古不枋東宗地所明細』尚 玄堂によったが，1881 年当時もこの評価額であったこと は，橋本町 1 3 丁目の「地券面は二万三千余」(郵 便 報知新聞 1 月 31 日付）の額との一致からもわかる。

40）郵便報知新聞 1 月 31 日付。

41）同上小よび同紙 2 月 3 日付。

42) 後に扂付地主 11 名が連名で土地評価がえについて請覑し た文章でもこの点を指摘している。しかし，この請願の 趣旨牥評価がえの延期である（前揭『共有地回議録』）。

43） 1880 年 11 月に設けら机た市区改正取調委員のことを指 すものと思われる。

44）久右衛門町の西側浅草橋よりにあった旧関東郡代屋舗あ と。明治以来諸県出張所となり，1872 年市街地となって 馬喰町 4 丁目之称した（『東京拊志料』第五，1951 年復 刻版 p. 73)。

45）この道路恃江戸時代から存在していたものである。

46）前揭「市区改正八果シテ衛生上ノ問題二非ザルカ」 


\section{S Y NOPSIS}

UDC $711.14(52127 \mathrm{~K})$ “1881"

\section{THE SLUM CLEARANCE PROJECT IN THE CENTRAL DISTRICT OF TOKYO IN 1881, A CASE OF KANDA HASHIMOTO-CHŌ.}

PART I. Purchase of whole area.

by YORIFUSA ISHIDA, Associate prof. of Tokyo Metropolitan Univ., Member of A.I.J.

Kanda Hashimoto-chō which had been one of four noted slums in Tokyo, was cleared in 1881 . In this study the author intended to make clear the detail and background of this slum clearance.

Contents of part-1 are as follows :

1) Overcrowded condition of Hashimoto-chō.

2) The big fire on the 26th of January 1881, which redused the slum ashes.

3) A bill to purchase the whole area of slum was discussed and adopted in the extraordinary session of Tokyo 15 Wards assembly.

4) Actual process of purchase.

5) Background of the clearance.

In examining the background of this slum clearance, the author mentions a paper written in 1889 by Ōgai (Rintarō) Mori (famous novelist and doctor) which criticized such opinions that to segregate the poor from the Central District of Tokyo would be the essencial mehtod to prevent big fire and to improve hygienic condition.

Conclusion of part-1 is that the clearance of Hashimoto-chō was the plain example of improvement project used as a expedient of segregation. 